\title{
Effect of undigested neutral detergent fiber content of alfalfa hay on lactating dairy cows: Feeding behavior, fiber digestibility, and lactation performance
}

\author{
M. Fustini, ${ }^{* 1}$ A. Palmonari, ${ }^{\star 1,2}$ G. Canestrari, ${ }^{*}$ E. Bonfante, ${ }^{*}$ L. Mammi, ${ }^{*}$ M. T. Pacchioli, $\dagger$ G. C. J. Sniffen, $\ddagger$ \\ R. J. Grant,§ K. W. Cotanch,§ and A. Formigoni* \\ *Department of Veterinary Medicine, Università di Bologna, 40064 Bologna, Italy \\ †C.R.P.A. Centro Ricerche Produzioni Animali S.p.A., 42121 Reggio Emilia, Italy \\ łFencrest LLC, Holderness, NH 03245 \\ §William H. Miner Agricultural Research Institute, Chazy, NY 12921
}

\section{ABSTRACT}

The objective of this study was to investigate the effects of 2 alfalfa hays differing in undigested neutral detergent fiber content and digestibility used as the main forage source in diets fed to high producing cows for Parmigiano-Reggiano cheese production. Diets were designed to have 2 different amounts of undigestible NDF [high $(\mathrm{Hu})$ and low $(\mathrm{Lu})]$, as determined by 240 -h in vitro analysis $\left(\mathrm{uNDF}_{240}\right)$. Alfalfa hay in vitro digestibility [\% of amylase- and sodium sulfite-treated NDF with ash correction (aNDFom)] at 24 and $240 \mathrm{~h}$ was 40.2 and $31.2 \%$ and 53.6 and $45.7 \%$ for low- (LD) and high-digestibility (HD) hays, respectively. The 4 experimental diets $(\mathrm{Hu}-\mathrm{HD}, \mathrm{Lu}-\mathrm{HD}, \mathrm{Hu}-\mathrm{LD}$, and $\mathrm{Lu}-$ LD) contained $46.8,36.8,38.8$, and $30.1 \%$ of alfalfa hay, respectively, $8.6 \%$ wheat straw, and $35.3 \%$ corn $(50 \%$ flake and $50 \%$ meal; DM basis). Soy hulls and soybean meal were used to replace hay to balance protein and energy among diets. Eight multiparous Holstein cows (average milk production $=46.0 \pm 5.2 \mathrm{~kg} / \mathrm{d}, 101 \pm 38$ $\mathrm{d}$ in milk, and $662 \pm 42 \mathrm{~kg}$ of average body weight) were assigned to a $4 \times 4$ Latin square design, with $2 \mathrm{wk}$ of adaptation and a 1-wk collection period. Dry matter and water intake, rumination time, ruminal $\mathrm{pH}$, and milk production and composition were measured. Diets and feces were analyzed for NDF on an organic matter basis (aNDFom), acid detergent fiber, acid detergent lignin, and $\mathrm{uNDF}_{240}$ to estimate total-tract fiber digestibility. Dry matter intake and rumination times were higher in HD diets compared with LD diets, regardless of forage amount. Rumination time was constant per unit of dry matter intake but differed when expressed as a function of $\mathrm{uNDF}_{240}$, aNDFom, or physically effective NDF intake. No differences were found among

Received November 7, 2016.

Accepted February 1, 2017.

${ }^{1}$ These authors contributed equally to this work.

${ }^{2}$ Corresponding author: alberto.palmonari2@unibo.it treatments on average ruminal $\mathrm{pH}$, but the amount of time with $\mathrm{pH}<5.8$ was lower in $\mathrm{Hu}-\mathrm{HD}$ diets. Milk production and components were not different among diets. Total-tract aNDFom and potentially digestible neutral detergent fiber fraction digestibility was higher for the LD diets (88.3 versus $85.8 \%$ aNDFom in HD), for which lower feed intakes were also observed. The $\mathrm{Hu}-\mathrm{HD}$ diet allowed greater dry matter intake, longer rumination time, and higher ruminal $\mathrm{pH}$, suggesting that the limiting factor for dry matter intake is neutral detergent fiber digestibility and its relative rumen retention time.

Key words: alfalfa hay digestibility, $\mathrm{uNDF}_{240}$, totaltract digestibility

\section{INTRODUCTION}

Fiber plays a physical role in stimulating chewing, peristalsis of the gastrointestinal tract, and proper digestive function. Chewing is essential to rapidly reduce particle size of feeds, increase surface area for attachment of ruminal microorganisms, stimulate saliva production, and exert ruminal $\mathrm{pH}$ control. Peristalsis allows rumen mixing, which is one of the key elements of efficient digestion of feeds. This creates a more homogeneous environment and controls particle retention or escape from the rumen. (Van Soest, 1994). Rumination activity is closely related to ruminal fill due to activation of pressure and stretching receptors in the reticulorumen wall (Van Soest, 1994) and to the particle size of different feedstuffs (Fustini et al., 2011).

The fiber content of the diet, as well as its physical characteristics such as particle size, density, fragility, and digestibility, appear to be the main factors responsible for ruminal fill and daily DMI (Conrad et al., 1964). This physical fill control system is more evident when cows are fed for ad libitum intake and during the first phase of lactation, during which metabolic and endocrine signals are less effective to control appetite (Allen and Piantoni, 2014). Kendall et al. (2009) studied 
the effect of amylase- and sodium sulfite-treated NDF with ash correction (aNDFom) digestibility on intake and milk production and observed an improvement in feed intake and milk production when in vitro aNDFom digestibility of the diets increased.

Oba and Allen (1999) evaluated the relationship of NDF digestibility (NDFD) and animal performance and estimated that a $1-\mathrm{U}$ increase in forage NDFD in vitro or in situ was associated with increases of 0.17 $\mathrm{kg} / \mathrm{d}$ of DMI, $0.23 \mathrm{~kg} / \mathrm{d}$ of milk yield, and $0.25 \mathrm{~kg} / \mathrm{d}$ of $4.0 \%$ FCM.

The indigestible NDF (iNDF) content of the diet is receiving increased interest for measuring the dietary physical filling effect that may limit feed intake. The iNDF represents the amount of fiber that, by definition, is not subject to the digestive process in the digestive tract (Huhtanen et al., 2007) and can be estimated using 240 -h in vitro fermentation $\left(\mathbf{u N D F}_{\mathbf{2 4 0}}\right.$; Palmonari et al., 2016) or in vivo degradation for $288 \mathrm{~h}$; the latter, however, is strictly related to the availability of ruminally cannulated cows and to the bag characteristics (Krizsan et al., 2012).

The utilization of dietary $\mathrm{uNDF}_{240}$ as a feed constraint on animal performance and feeding behavior has not been fully investigated. Forage $\mathrm{uNDF}_{240}$ content varies across plant species and within species and is influenced by many factors, such as hybrid genetics, growing conditions, and maturity at harvest (Palmonari et al., 2014, 2016).

Our study was conducted to investigate the effect of feeding diets that differed in dietary $\mathrm{uNDF}_{240}$ concentration and in vitro NDFD of alfalfa hay on DMI, total-tract fiber digestibility, rumination, ruminal $\mathrm{pH}$, and milk production in high-producing dairy cows. Our hypothesis was that diets containing greater $\mathrm{uNDF}_{240}$ would stimulate more chewing, reduce total-tract fiber digestibility, and thereby limit feed intake and milk production.

\section{MATERIALS AND METHODS}

This study was conducted at the University of Bologna (Italy) and all experimental procedures involving animals were approved by the University of Bologna Animal Care and Use Committee.

\section{Animals and Experimental Design}

Eight multiparous Holstein cows (parity $=3.63 \pm$ $0.92,101 \pm 38 \mathrm{DIM}$, and $662 \pm 42 \mathrm{~kg}$ of BW) were blocked by parity, milk production, and DIM, and used in a replicated $4 \times 4$ Latin square design with 21 -d periods: $14 \mathrm{~d}$ of adaptation and $7 \mathrm{~d}$ of collection. Rations were formulated to mimic a common TMR used for Parmigiano-Reggiano cheese production utilizing only dry forages and ingredients that are commonly used in the region (Table 1; Mordenti et al., 2015). Diets were formulated using NDS Professional (R.U.M.\&N, Reggio Emilia, Italy), a software based on the Cornell Net Carbohydrate and Protein System equations (CNCPS v.6.5; Van Amburgh et al., 2015). Forages included in the experimental diet were finely chopped to avoid sorting. Particles distribution was measured using the Penn State Particle Separator. Forage particle length in TMR was less than $2 \mathrm{~cm}$, as commonly applied in the Parmigiano-Reggiano area (Table 2).

The 4 experimental diets were balanced for starch and $\mathrm{CP}$ content while differing in forage source and amount of $\mathrm{uNDF}_{240}$ (Table 2). Treatments were defined as high $\mathrm{uNDF}_{240}$ content, highly digestible alfalfa hay $(\mathbf{H D}-\mathrm{Hu})$; low $\mathrm{uNDF}_{240}$ content, highly digestible alfalfa hay (HD-Lu); high $\mathrm{uNDF}_{240}$ content, low-digestibility alfalfa hay (LD-Hu); and low $\mathrm{uNDF}_{240}$ content, low-digestibility alfalfa hay (LD-Lu). Alfalfa hay was the major forage source. Differences in fiber fractions were balanced using soy hulls, which are characterized by very low $\mathrm{uNDF}_{240}$ content and serve as a good fiber

Table 1. Chemical composition of the dietary forages (mean \pm SD)

\begin{tabular}{|c|c|c|c|}
\hline Item & $\begin{array}{l}\text { High-digestibility alfalfa hay } \\
\qquad(\mathrm{n}=32)\end{array}$ & $\begin{array}{l}\text { Low-digestibility alfalfa hay } \\
\qquad(\mathrm{n}=32)\end{array}$ & $\begin{array}{l}\text { Wheat straw } \\
\qquad(\mathrm{n}=7)\end{array}$ \\
\hline $\mathrm{DM}$ & $92.7 \pm 0.8$ & $91.9 \pm 0.7$ & $91.5 \pm 1.1$ \\
\hline $\mathrm{CP}, \%$ of $\mathrm{DM}$ & $20.5 \pm 1.5$ & $18.5 \pm 1.1$ & $4.6 \pm 0.3$ \\
\hline aNDFom, ${ }^{1} \%$ of DM & $36.7 \pm 2.2$ & $44.5 \pm 2.8$ & $72.0 \pm 2.6$ \\
\hline $\mathrm{ADF}, \%$ of $\mathrm{DM}$ & $30.1 \pm 1.2$ & $36.1 \pm 1.4$ & $49.2 \pm 1.5$ \\
\hline $\mathrm{ADL}, \%$ of DM & $7.1 \pm 0.6$ & $7.5 \pm 0.8$ & $9.7 \pm 0.8$ \\
\hline IVNDFD $^{2} 24 \mathrm{~h}, \%$ of NDF & $40.2 \pm 3.8$ & $31.2 \pm 4.2$ & $34.9 \pm 3.5$ \\
\hline $\mathrm{uNDF}_{240},{ }^{3} \%$ of DM & $15.7 \pm 1.4$ & $18.5 \pm 1.7$ & $32.3 \pm 2.1$ \\
\hline $\mathrm{uNDF}_{240}, \%$ of aNDFom & $40.5 \pm 3.1$ & $44.3 \pm 2.8$ & $45.4 \pm 2.5$ \\
\hline $\mathrm{uNDF}_{240} / \mathrm{ADL}$ & 2.21 & 2.47 & 3.33 \\
\hline
\end{tabular}

${ }^{1}$ aNDFom $=$ amylase- and sodium sulfite-treated NDF with ash correction.

${ }^{2}$ IVNDFD $=$ in vitro NDF digestibility as a percent of aNDFom.

${ }^{3} \mathrm{uNDF}_{240}=$ undigested NDF estimated via $240-\mathrm{h}$ in vitro fermentation. 
Table 2. Ingredient and chemical composition of the experimental diets

\begin{tabular}{|c|c|c|c|c|c|}
\hline \multirow[b]{2}{*}{ Item } & \multicolumn{4}{|c|}{ Treatment $^{1}$} & \multirow[b]{2}{*}{ SEM } \\
\hline & $\mathrm{Hu}-\mathrm{HD}$ & Lu-HD & $\mathrm{Hu}-\mathrm{LD}$ & $\mathrm{Lu}-\mathrm{LD}$ & \\
\hline \multicolumn{6}{|l|}{ Ingredient, $\%$ of DM } \\
\hline Alfalfa hay (HD) & 46.8 & 36.8 & - & - & \\
\hline Alfalfa hay (LD) & - & - & 38.8 & 30.1 & \\
\hline Wheat straw & 8.6 & 8.6 & 8.6 & 8.6 & \\
\hline Corn grain mix $^{2}$ & 35.3 & 35.3 & 35.3 & 35.3 & \\
\hline Soybean hulls & 4.0 & 11.0 & 8.0 & 15.4 & \\
\hline Soybean meal, $44 \%$ CP & 3.0 & 6.0 & 7.0 & 8.3 & \\
\hline Cane-beet molasses blend & 0.5 & 0.5 & 0.5 & 0.5 & \\
\hline Vitamin and mineral premix ${ }^{3}$ & 1.8 & 1.8 & 1.8 & 1.8 & \\
\hline Forage content, \% of DM & 55.4 & 45.4 & 47.4 & 38.7 & \\
\hline \multicolumn{6}{|l|}{ Chemical composition, $\%$ of DM } \\
\hline $\mathrm{CP}$ & 14.3 & 14.2 & 14.5 & 14.9 & 0.11 \\
\hline aNDFom $^{4}$ & 31.7 & 32.3 & 34.4 & 35.2 & 0.31 \\
\hline Starch & 23.1 & 22.6 & 22.7 & 22.9 & 0.22 \\
\hline Sugar & 5.9 & 5.3 & 5.2 & 4.6 & 0.05 \\
\hline Ash & 6.8 & 6.6 & 6.4 & 6.4 & 0.07 \\
\hline $\mathrm{Ca}$ & 0.96 & 0.98 & 0.97 & 0.97 & 0.09 \\
\hline $\mathrm{P}$ & 0.48 & 0.47 & 0.47 & 0.48 & 0.04 \\
\hline $\mathrm{uNDF}_{240},{ }^{5} \%$ of aNDFom & 35.2 & 29.1 & 32.0 & 27.0 & 0.28 \\
\hline $\mathrm{uNDF}_{240}, \%$ of DM & 10.8 & 9.4 & 11.0 & 9.5 & 0.10 \\
\hline IVNDFD $^{6} 24 \mathrm{~h}, \%$ of aNDFom & 46.2 & 48.9 & 43.8 & 44.6 & 0.44 \\
\hline \multicolumn{6}{|l|}{ Particle size, $\%$ of as fed } \\
\hline$>19 \mathrm{~mm}$ & 0.7 & 0.4 & 0.3 & 0.2 & \\
\hline $19-8 \mathrm{~mm}$ & 16.8 & 13.5 & 12.5 & 9.7 & \\
\hline $8-1.18 \mathrm{~mm}$ & 41.3 & 39.4 & 36.1 & 34.2 & \\
\hline Pan & 41.2 & 46.8 & 51.2 & 55.9 & \\
\hline peNDF, ${ }^{7} \%$ of DM & 12.9 & 12.8 & 11.6 & 11.2 & \\
\hline
\end{tabular}

${ }^{1} \mathrm{Hu}-\mathrm{HD}=$ high $\mathrm{uNDF}_{240}$ content, highly digestible alfalfa hay; Lu-HD = low $\mathrm{uNDF}_{240}$ content, highly digestible alfalfa hay; $\mathrm{Hu}-\mathrm{LD}=$ high $\mathrm{uNDF}_{240}$ content, low-digestible alfalfa hay; Lu-LD = low $\mathrm{uNDF}_{240}$ content, low-digestible alfalfa hay.

${ }^{2}$ Corn grain mix: $50 \%$ fine meal, $50 \%$ flakes.

${ }^{3}$ Vitamin mineral mix: 4.4\% Ca, 2.3\% P, $6 \% \mathrm{Na}, 2.5 \% \mathrm{Mg}, 130 \mathrm{mg} / \mathrm{kg}$ of Zn, $120 \mathrm{mg} / \mathrm{kg}$ of Mn, $10 \mathrm{mg} / \mathrm{kg}$ of $\mathrm{Cu}, 5 \mathrm{mg} / \mathrm{kg}$ of I, $0.15 \mathrm{mg} / \mathrm{kg}$ of Se, $1 \mathrm{mg} / \mathrm{kg}$ of Co, 40,000 IU $/ \mathrm{kg}$ of vitamin A, 4,000 IU $/ \mathrm{kg}$ of vitamin $\mathrm{D}_{3}$, and $40 \mathrm{mg} / \mathrm{kg}$ of vitamin $\mathrm{E}$.

${ }^{4}$ aNDFom $=$ amylase- and sodium sulfite-treated NDF with ash correction.

${ }^{5} \mathrm{uNDF}_{240}=$ undigested NDF estimated via 240 -h in vitro fermentation.

${ }^{6} \mathrm{IVNDFD}=$ in vitro NDF digestibility as \% of aNDFom.

${ }^{7}$ peNDF $=$ physically effective NDF, calculated using the Ro-Tap system (Mertens, 1997).

source for altering dietary $\mathrm{uNDF}_{240}$ content with minimum confounding of other nutrient fractions.

Cows were housed in a tiestall barn equipped with individual feed mangers. Dry TMR was prepared in a Zago Mixer (Zago Srl, Padova, Italy) and delivered for ad libitum intake $(1.08 \times$ expected intake $)$ once daily while the animals were milked $(0800 \mathrm{~h})$. Cows were milked twice a day (0800, and $1900 \mathrm{~h}$ ) in a double-5 milking parlor and were away from feed $<30 \mathrm{~min} /$ milking. The amounts of feed offered and refused were weighed daily for each cow. Water was provided to all cows for ad libitum consumption and measured daily.

Body weight was recorded 2 times a day after milking (Afiweight scale, Afimilk, Kibbutz Afikim, Israel). The DMI was determined by recording feed offered and refused in each experimental period. Samples of diets and orts were collected daily and a portion of each sample was dried in a forced-air oven at $105^{\circ} \mathrm{C}$ for $24 \mathrm{~h}$ for $\mathrm{DM}$ determination. Milk yield was recorded daily (Afimilk Information Management System). Milk samples from 3 consecutive milkings for each cow were collected on d 17 and 18 of each period, preserved (Bronolab-W II Liquid Preservative; D \& F Control Systems Inc., Dublin, CA), and analyzed for fat, true protein, and lactose by mid-infrared (Associazione Provinciale Allevatori Bologna; Foss 4000; Foss Analytic, Hillerød, Denmark). Feed efficiency $(\mathrm{kg} / \mathrm{kg})$ was calculated as milk/DMI, $3.5 \%$ FCM/DMI, and solids-corrected milk/DMI for d 15 through 21 of each period.

Rumination time was measured using the Hi-Tag rumination monitoring system (SCR Engineers Ltd., Netanya, Israel). Data Flow software (SCR Engineers Ltd.) analyzed the rumination time as minutes within $2 \mathrm{~h}$ with a resolution of $2 \mathrm{~min}$ (Schirmann et al., 2009), 
and calculated the rumination time of the last $24 \mathrm{~h}$. All cows received an indwelling wireless $\mathrm{pH}$-transmitting unit (SmaXtec Animal Care Sales GmbH, Graz, Austria), which has been validated in a dairy cattle experiment with rumen-cannulated cows (Klevenhusen et al., 2014). These units (3.5 cm i.d., $12 \mathrm{~cm}$ long, and weighing $210 \mathrm{~g}$ ) were manually inserted into the reticulorumen via the esophagus on d 14 of the first period. Prior to this, the units were calibrated by a 1-point calibration using a buffer of $\mathrm{pH} 7.0$ following the company's instruction protocol. The units measured $\mathrm{pH}$ and temperature every $10 \mathrm{~min}$ and transmitted the data in real time to a base station using the industrial, scientific, and medical (ISM) band (433 MHz). Antennae installed in the barn and milking parlor registered the sensor signals. The $\mathrm{pH}$ data were collected using an analog-to-digital converter and stored in an external memory chip. The measurements were taken continuously from each cow until the end of the experiment. The $\mathrm{pH}$ data from $\mathrm{d}$ 15 to 21 of each period were analyzed as daily mean $\mathrm{pH}$ and time (min/d) below specific cutoff points (5.5 and 5.8).

Dietary ingredients were analyzed and stored at the beginning of the trial in an amount to guarantee ad libitum access to feed during the whole experiment and to reduce dietary variability during the experiment. During the experimental week of each period, diets were sampled daily and analyzed for chemical composition according to the following methods. Crude protein, aNDFom, and ADF were determined according to Mertens et al. (2002) and AOAC (1990) method 973.18. Starch was determined according to AOAC official method 996.11 and ether extract according to AOAC 920.390020. Fecal samples (500 g) were collected every $15 \mathrm{~h}$ from d 11 to 15 of each experimental period so that 8 samples were taken for each cow in each period, representing every $3 \mathrm{~h}$ of a 24 -h period to account for diurnal variation. Samples were stored at $-20^{\circ} \mathrm{C}$.

Forage and dietary composite samples were used to determine particle size distribution on an as-fed basis using the Penn State Particle Separator (Lammers et al., 1996) and physical effectiveness factor using a RoTap Separator (W.S. Tyler, Mentor, OH). Physically effective NDF of a forage or diet was calculated as the product of its NDF content and its physical effectiveness factor (Mertens, 1997). In vitro digestibility (24 and $240 \mathrm{~h}$ ) of aNDFom of forage and diet composite samples (1-mm grind; Wiley mill, Arthur H. Thomas, Philadelphia, PA) were determined using an in vitro fermentation (Tilley and Terry, 1963) in buffered medium containing ruminal fluid (Goering and Van Soest, 1970).

\section{Fiber Digestibility}

Ingredients and diets were analyzed for in vitro aNDFom digestibility (IVNDFD) at 24 and $240 \mathrm{~h}$ according to the procedure described by Palmonari et al. (2016). Digestibility was calculated as

$$
\begin{gathered}
\text { IVNDFD }, \% \text { of aNDFom }= \\
{\left[1-\left(\operatorname{aNDFom}_{\mathrm{r}}-\mathrm{aNDFom}_{\mathrm{b}}\right) / \mathrm{aNDFom}_{\mathrm{i}}\right] \times 100,[1]}
\end{gathered}
$$

where $\mathrm{aNDFom}_{\mathrm{r}}$ is the residual aNDFom, $\mathrm{aNDFom}_{\mathrm{b}}$ is the blank correction, and $\mathrm{aNDFom}_{\mathrm{i}}$ represents the initial aNDFom. All the described terms are expressed in grams. The unavailable aNDFom fraction was determined after $240 \mathrm{~h}$ of in vitro fermentations and calculated as

$$
\begin{gathered}
\mathrm{uNDF}_{240}, \% \text { of DM }= \\
(100-\text { IVNDFD240h }) \times \text { aNDFom } / 100,
\end{gathered}
$$

where aNDFom is the aNDFom content of the sample on a DM basis, and IVNDFD240h is the in vitro digestibility at $240 \mathrm{~h}$ of the aNDFom fraction.

For the IVNDFD240h fermentation, both rumen fluid and buffer were reinoculated after $120 \mathrm{~h}$ to preserve the microbial activity during the whole process, as described by Palmonari et al. (2014). Total-tract potentially digestible NDF (pdNDF) digestibility (TTpdNDFD) was calculated according to Ferraretto et al. (2015). Briefly, $\mathrm{uNDF}_{240}$ was used as an internal marker and digestibility was expressed as

$$
\begin{gathered}
\text { TTpdNDFD, } \% \text { pdNDF }=100-\left[\left(\text { dietary } \mathrm{uNDF}_{240} /\right.\right. \\
\text { fecal } \left.\mathrm{uNDF}_{240}\right) \times(\text { fecal pdNDF concentration } / \\
\text { dietary pdNDF })],
\end{gathered}
$$

where both pdNDF and $\mathrm{uNDF}_{240}$ are expressed in percent of DM.

\section{Statistical Analysis}

Data for DMI, water intake, milk yield and composition, feed efficiency, and BW were analyzed as a replicated Latin square design with model effects for diet, period, and replicate using the MIXED procedure of SAS (version 9.1, SAS Institute Inc., Cary, NC), using cow within replicate as a random effect. Repeated measurements on performance data (i.e., DMI and milk yield) were reduced to period means for each cow before statistical analysis. The model included the effects 
of diet, period, time, and the interaction of diet and time with cow as a random effect. Least squares means were separated using the Tukey's procedure when a significant $F$-test $(P \leq 0.05)$ was detected.

\section{RESULTS AND DISCUSSION}

The 4 treatments were designed to have 2 levels of $\mathrm{uNDF}_{240}$ in the diets (10.8 and $11.0 \%$ of DM for Hu diets and 9.5 and $9.4 \%$ of DM in Lu diets) using 2 alfalfa hays differing in NDFD and $\mathrm{uNDF}_{240}$. The 2 alfalfa hays were different in IVNDFD $24 \mathrm{~h}(40.2 \pm 3.8$ and $31.2 \pm 4.2 \%$ aNDFom for HD and LD, respectively), in $\mathrm{uNDF}_{240}$ content $(15.7 \pm 1.4$ and $18.5 \pm 1.7 \%$ of DM for $\mathrm{HD}$ and $\mathrm{LD}$, respectively), and in total aNDFom $(36.7 \pm 2.2$ and $44.5 \pm 2.8 \%$ of $\mathrm{DM}$ for $\mathrm{HD}$ and $\mathrm{LD}$, respectively; Table 1).

The diets with the inclusion of HD alfalfa had a total IVNDFD $24 \mathrm{~h}$ of 46.2 and $48.9 \%$ of aNDFom (HD-Hu and HD-Lu, respectively). As expected, LD diets had lower IVNDFD $24 \mathrm{~h}$ (43.8 and $44.6 \%$ aNDFom for LD$\mathrm{Hu}$ and LD-Lu, respectively; SEM $=0.44$. Table 2). The $\mathrm{uNDF}_{240}$-to-ADL ratio between alfalfa hays was comparable to that observed by previous studies (Palmonari et al., 2014) that had similar forage growing conditions.

All diets had a relatively short particle size (Table 2 ), as is common in the Parmigiano-Reggiano area. The shorter dietary particle size allows for minimal feed sorting while using all dry ingredients (Fustini et al., 2016). It is typical for these diets to have less than $1 \%$ particles greater than $19 \mathrm{~mm}$ and a high percentage on the lower sieves ( 8 to $1.18 \mathrm{~mm}$ ) and bottom pan. The physically effective NDF (peNDF) values of the diets were $12.9,12.8,11.6$, and $11.2 \%$ of $\mathrm{DM}$ for the HD-Hu, HD-Lu, LD-Hu, and LD-Lu diet, respectively (SEM = 0.12 ). These values are lower than the minimum peNDF requirement suggested by Mertens (1997; 21.0\% of DM). In a previous study Fustini et al. (2010) showed that in typical Parmigiano-Reggiano diets the inclusion of wheat straw could maintain rumination time and ruminal $\mathrm{pH}$ above 5.5, even at low peNDF values. Due to this reason, all diets included $8.6 \%$ wheat straw (DM basis) to provide $\mathrm{uNDF}_{240}$ and slowly digestible NDF. Calculation of peNDF using NDF content times the percentage of particles larger than $1.18 \mathrm{~mm}$ determined by Ro-Tap separation (Tyler Industrial Group, Mentor, $\mathrm{OH}$ ) underestimate the peNDF content of diets that include straw (Fustini et al., 2011). Consequently, straw may have a small peNDF measured using dry sieving but still have potential to promote more chewing per kilogram of NDF at the same particle size. The dietary composition in terms of $\mathrm{CP}, \mathrm{NDF}$, starch, sugar, and minerals were as planned and typical of those used in this region of Italy (Table 2 ).

Dry matter intake data are reported in Table 3. The highly digestible alfalfa led to an increased DMI, regardless of the forage-to-concentrate ratio of the diet (29.7, $29.2,24.5$, and $24.5 \mathrm{~kg} / \mathrm{d}, \mathrm{SEM}=0.40, P<0.01$, for $\mathrm{HD}-\mathrm{Hu}, \mathrm{HD}-\mathrm{Lu}, \mathrm{LD}-\mathrm{Hu}$, and LD-Lu, respectively). Dry matter intake was $0.61 \mathrm{~kg}$ higher for each additional point of alfalfa IVNDFD $24 \mathrm{~h}$. A possible reason could be the main forage source used in the current study. As discussed by Voelker Linton and Allen (2010), the filling effect of legumes is generally less than grasses and independent of fiber digestibility. This difference between legumes and grasses is related to faster fiber digestibility and greater particle fragility for legumes, which decreases retention time in the rumen and results in an improved DMI (Mertens and Huhtanen, 2007; Kammes and Allen, 2012). Similar to DMI, water intake was also influenced by forage digestibility and was greater with higher NDF digestibility of alfalfa $(P$ $<0.01)$. This difference was not observed when daily water intake was related to DMI, suggesting a similar effect of ingestion even in different diets (Table 3).

Daily intake of $\mathrm{uNDF}_{240}$ was affected by both digestibility and forage inclusion $(P<0.01)$, and higher values were obtained for the HD-Hu treatment $(3.21,2.74$, 2.70 and $2.33 \mathrm{~kg} / \mathrm{d}, \mathrm{SEM}=0.04, P<0.01$, for HD-Hu, $\mathrm{HD}-\mathrm{Lu}, \mathrm{LD}-\mathrm{Hu}$, and $\mathrm{LD}-\mathrm{Lu}$, respectively). Forage digestibility (HD vs. LD diets) also influenced aNDFom intake $(9.39,9.81,8.77,9.07 \mathrm{~kg} / \mathrm{d}, \mathrm{SEM}=0.17, P<$ 0.05, for HD-Hu, HD-Lu, LD-Hu, and LD-Lu, respectively). The fraction of aNDFom digested in vitro at 24 $\mathrm{h}$ represents the majority of the rapidly digestible fiber and a small amount of the slowly digestible one. After determining IVNDFD24h it is possible to measure the undegraded fiber at $24 \mathrm{~h}$ of fermentation. The 4 treatments in this study had the same intake of this fraction (Table 3), expressed as amount or percentage of BW $(0.75,0.73,0.74$, and $0.75 \% \mathrm{BW}, \mathrm{SEM}=0.01, P>$ 0.05, for HD-Hu, HD-Lu, LD-Hu, and LD-Lu, respectively). The portion of aNDFom that is rapidly digested in the rumen has a considerably lower ruminal-filling effect compared with the slower-digesting and unavailable fiber fractions. As suggested by Huhtanen et al. (2016), fiber is retained in the rumen while the potentially digestible fraction is actively fermenting. When the pdNDF-to-iNDF ratio decreases (due to microbial fermentations), particles have a higher probability of leaving the rumen due to an increased specific gravity. This particular dynamic of digestion could explain the results of the current study. In fact, the DMI is not limited by the dietary $\mathrm{uNDF}_{240}$ content alone, but by a combination of $\mathrm{uNDF}_{240}$ and the amount of slowly 
Table 3. Effect of forage digestibility and diet undigested NDF content on feed and water intake

\begin{tabular}{|c|c|c|c|c|c|c|c|c|}
\hline Daily intake & \multicolumn{4}{|c|}{ Treatment $^{1}$} & SEM & \multicolumn{3}{|c|}{$P$-value } \\
\hline $\mathrm{DM}, \mathrm{kg} / \mathrm{d}$ & 29.7 & 29.2 & 24.5 & 24.5 & 0.4 & $<0.01$ & 0.89 & 0.99 \\
\hline aNDFom, ${ }^{3} \mathrm{~kg} / \mathrm{d}$ & 9.39 & 9.81 & 8.77 & 9.07 & 0.17 & $<0.05$ & 0.51 & 0.86 \\
\hline aNDFom, $\%$ of BW & 1.36 & 1.38 & 1.26 & 1.29 & 0.02 & $<0.05$ & 0.45 & 0.96 \\
\hline $\mathrm{uNDF}_{24},{ }^{4} \mathrm{~kg} / \mathrm{d}$ & 5.05 & 5.01 & 4.93 & 5.02 & 0.09 & 0.79 & 0.90 & 0.79 \\
\hline Water, L/d & 169 & 173 & 164 & 163 & 2 & $<0.01$ & 0.64 & 0.52 \\
\hline Water, L/kg of DMI & 5.8 & 6.0 & 6.7 & 6.7 & 0.1 & 0.10 & 0.58 & 0.74 \\
\hline
\end{tabular}

${ }^{1} \mathrm{Hu}-\mathrm{HD}=$ high $\mathrm{uNDF}_{240}$ content, highly digestible alfalfa hay; Lu-HD = low $\mathrm{uNDF}_{240}$ content, highly digestible alfalfa hay; Hu-LD = high $\mathrm{uNDF}_{240}$ content, low-digestible alfalfa hay; Lu-LD = low $\mathrm{uNDF}_{240}$ content, low-digestible alfalfa hay.

${ }^{2} \mathrm{I}=$ effect of the interaction among treatments.

${ }^{3}$ aNDFom $=$ amylase- and sodium sulfite-treated NDF with ash correction.

${ }^{4} \mathrm{uNDF}_{24}=$ undigested NDF estimated via 24 -h in vitro fermentation.

${ }^{5} \mathrm{uNDF}_{240}=$ undigested NDF estimated via 240 -h in vitro fermentation.

and rapidly fermenting fiber that together influence the pdNDF-to- iNDF ratio over time in the rumen. This effect might be more pronounced in the current experiment, considering that alfalfa was the main forage used; in fact, as discussed by Kammes and Allen (2012), rates of particle size reduction and passage are faster for legumes compared with cool-season grass, resulting in lower ruminal fill and less effective fiber. Milk production was not different $(P>0.05)$ among the diets, which may be due to the short duration of the study periods (Table 4). Milk fat was higher for cows fed the LD diets, as would be expected $(3.48,3.39$, 3.57 , and $3.51 \%, \mathrm{SEM}=0.02, P<0.01$, for $\mathrm{HD}-\mathrm{Hu}$, $\mathrm{HD}-\mathrm{Lu}, \mathrm{LD}-\mathrm{Hu}$, and $\mathrm{LD}-\mathrm{Lu}$, respectively), and milk protein percentage was lower for cows fed the $\mathrm{Hu}$ diets (3.26 and 3.29\%, SEM =0.01 $P<0.01$, on average for $\mathrm{Hu}$ and Lu diets, respectively). The FCM yield tended to be greater for cows fed the Lu diets.

Rumination time for high-uNDF ${ }_{240}$ diets (Table 5) decreased, as would be expected due to the higher DMI of these diets. In addition to the increased rumination for $\mathrm{uNDF}_{240}$ (152 and $183 \mathrm{~min} / \mathrm{kg}, \mathrm{SEM}=3, P<0.01$, for $\mathrm{Hu}$ and $\mathrm{Lu}$ diets, respectively) and peNDF intake (135 and $141 \mathrm{~min} / \mathrm{kg}, \mathrm{SEM}=2, P<0.05$, for $\mathrm{Hu}$ and $\mathrm{Lu}$ diets, respectively), however, these diets had lower rumen $\mathrm{pH}$ and a longer time with low $\mathrm{pH}$ as a result of the higher amount of concentrates in these diets. The HD diets resulted in more minutes spent in ruminating compared with LD diets $(487,499,390$, and $410 \mathrm{~min} / \mathrm{d}$, $\mathrm{SEM}=6, P<0.01$, for HD-Hu, HD-Lu, LD-Hu, and LD-Lu, respectively). This effect could be related to the greater DMI of the HD diets, as a positive relationship is well-established between periods of high feed intake and rumination (Schirmann et al., 2012). No differences were observed among treatments when rumination was calculated as a function of DMI.

Daily average $\mathrm{pH}$ was not different among treatments $(P>0.05$; Table 5$)$. The observed tendency for $\mathrm{pH}$ to differ $(P=0.10)$ among $\mathrm{Hu}$ and $\mathrm{Lu}$ diets could suggest a positive effect of the forage inclusion on the average

Table 4. Average milk production and composition for dietary treatments

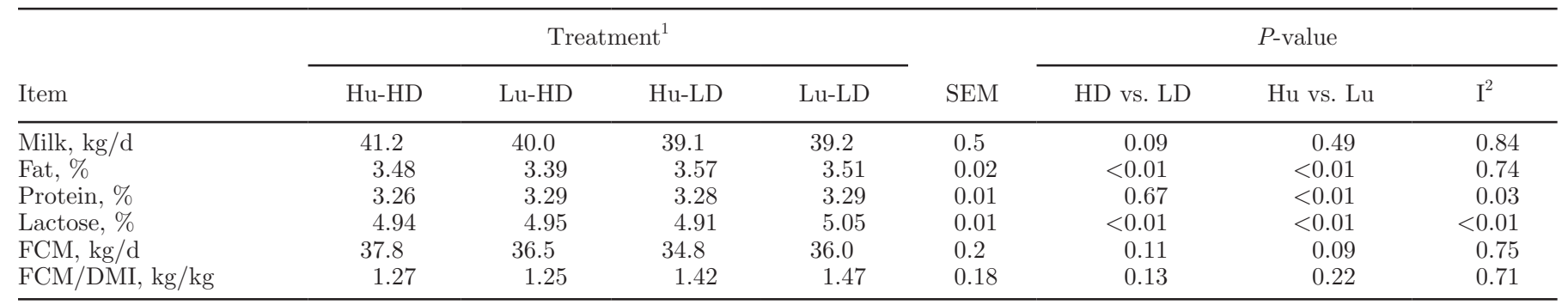

${ }^{1} \mathrm{Hu}-\mathrm{HD}=$ high undigested NDF estimated via 240-h in vitro fermentation $\left(\mathrm{uNDF}_{240}\right)$ content, highly digestible alfalfa hay; Lu-HD = low $\mathrm{uNDF}_{240}$ content, highly digestible alfalfa hay; Hu-LD = high $\mathrm{uNDF}_{240}$ content, low-digestible alfalfa hay; Lu-LD $=$ low uNDF 240 content, lowdigestible alfalfa hay.

${ }^{2} \mathrm{I}=$ effect of the interaction among treatments. 
Table 5. Average values of rumination and ruminal $\mathrm{pH}$ per treatment

\begin{tabular}{|c|c|c|c|c|c|c|c|c|}
\hline Measure & \multicolumn{4}{|c|}{ Treatment $^{1}$} & SEM & \multicolumn{3}{|c|}{$P$-value } \\
\hline \multicolumn{9}{|l|}{ Rumination, $\min / \mathrm{d}$} \\
\hline DMI, $\mathrm{kg}$ & 16.7 & 17.3 & 16.3 & 17.2 & 0.1 & 0.70 & 0.20 & 0.60 \\
\hline aNDFom $^{3}$ intake, $\mathrm{kg}$ & 50.4 & 55.4 & 43.7 & 50.1 & 0.9 & $<0.01$ & 0.70 & 0.24 \\
\hline $\mathrm{uNDF}_{240}{ }^{4}$ intake, $\mathrm{kg}$ & 155 & 184 & 148 & 181 & 3 & 0.44 & $<0.01$ & 0.56 \\
\hline $\mathrm{pH}<5.8, \mathrm{~min} / \mathrm{d}$ & 674 & 903 & 733 & 904 & 1 & 0.69 & $<0.01$ & 0.98 \\
\hline $\begin{array}{l}\mathrm{pH}<5.5, \mathrm{~min} / \mathrm{d} \\
\mathrm{AUC}^{6}\end{array}$ & 122 & 329 & 257 & 323 & 38 & 0.52 & 0.06 & 0.61 \\
\hline$<5.8, \mathrm{pH}$ units $\times \min / \mathrm{d}$ & 126 & 235 & 219 & 237 & 26 & 0.51 & 0.10 & 0.78 \\
\hline$<5.5, \mathrm{pH}$ units $\times \min / \mathrm{d}$ & 14 & 50 & 77 & 52 & 16 & 0.47 & 0.41 & 0.68 \\
\hline
\end{tabular}

${ }^{1} \mathrm{Hu}-\mathrm{HD}=$ high $\mathrm{uNDF}_{240}$ content, highly digestible alfalfa hay; Lu-HD = low $\mathrm{uNDF}_{240}$ content, highly digestible alfalfa hay; Hu-LD = high $\mathrm{uNDF}_{240}$ content, low-digestible alfalfa hay; Lu-LD = low $\mathrm{uNDF}_{240}$ content, low-digestible alfalfa hay.

${ }^{2} \mathrm{I}=$ effect of the interaction among treatments.

${ }^{3}$ aNDFom $=$ amylase- and sodium sulfite-treated NDF with ash correction.

${ }^{4} \mathrm{uNDF}_{240}=$ undigested NDF estimated via 240 -h in vitro fermentation.

${ }^{5}$ peNDF $=$ physically effective NDF, calculated using the Ro-Tap system (Mertens, 1997).

${ }^{6} \mathrm{AUC}=$ area under curve, calculated as the area below $\mathrm{pH}$ threshold (5.8 or 5.5) and above pH profiles of cows.

ruminal $\mathrm{pH}$. Moreover, the amount of time $(\mathrm{min} / \mathrm{d})$ spent with $\mathrm{pH}<5.8$ was higher in the Lu compared with the $\mathrm{Hu}$ diets $(674,903,733$, and $904 \mathrm{~min} / \mathrm{d}$, SEM $=1, P<0.01$, for HD-Hu, HD-Lu, LD-Hu, and LD-Lu, respectively). No differences were observed $(P>0.05)$ among $\mathrm{HD}$ and $\mathrm{LD}$ diets for average $\mathrm{pH}, \mathrm{pH}<5.8$, and $\mathrm{pH}<5.5(\mathrm{~min} / \mathrm{d})$. Time that $\mathrm{pH}$ was less than 5.8 was greater for Lu diets compared with Hu diets, suggesting an important role played by dietary forage amount in narrowing $\mathrm{pH}$ fluctuations rather than rumination time per se (Kmicikewycz, and Heinrichs, 2015).

Fecal chemical composition and total-tract digestibility of the pdNDF fraction are reported in Table 6. Dry matter content and fiber fractions were similar across treatments $(P>0.05)$. Total-tract digestibility for both aNDFom $(55.4,61.1,59.6$, and $64.9 \%$ aNDFom, SEM = 0.6, $P<0.01$, for HD-Hu, HD-Lu, LD-Hu, and LD-Lu, respectively) and pdNDF were different among $\mathrm{Hu}$ and $\mathrm{Lu}$ diets, being higher in the latter $(85.5,86.1,87.6$, and $88.9 \%$ pdNDF, SEM $=0.7, P<0.01$, for HD-Hu, HD-Lu, LD-Hu, and LD-Lu, respectively). In general, pdNDF was very well digested in all treatments, confirming the ability of the rumen to retain digestible fiber. It is possible that the lower digestibility of $\mathrm{LD}$ alfalfa was compensated for by the higher amount of soy hulls in the LD diets. Another reason could be the lower DMI of the LD diets, suggesting that fiber particles spent more time in the rumen, resulting in higher digestibility values. The observed total-tract digestibility of the pdNDF fraction was higher than currently predicted by some nutritional models (Van Amburgh et al., 2015), and the main factor influencing this function is not related to the forage fiber digestibility, but to the ability of the rumen to retain fiber.

Considering the results of the current study, it appears that DMI should be related to the rate of degradation of the pdNDF fraction, rather than $\mathrm{uNDF}_{240}$ intake per se. These data underline the ability of the rumen to retain forage particles rich in potentially digestible fraction, as reported by other authors (Huhtanen et al., 2007, 2016; Bayat et al., 2010; Krizsan et al., 2010). In particular, Bayat et al. (2010) reported a very slow passage rate for digestible particles, even if very finely chopped $(<1.25 \mathrm{~mm})$. This observation could be related to the buoyancy of such particles and the gas produced during the fermentation process. Feed particles have a higher probability to leave the rumen when they reach a critical dimension (due to chewing activity) and specific gravity. It has been reported that the passage rate of indigestible material is faster than that of the potentially digestible fraction (Krizsan et al., 2010), suggesting that the main filling effect of forages can be related to the rate of fermentation of pdNDF.

\section{CONCLUSIONS}

The results of our study suggest that DMI is very much influenced and improved by forage fiber digestibility (when it represents up to $50 \%$ of the ration and is mainly alfalfa hay) and not simply by the $\mathrm{uNDF}_{240}$ intake alone. The HD-Hu diet allowed higher milk production and ruminal $\mathrm{pH}$ values. When dietary peNDF percentage is low, good rumination time can be maintained only with higher DMI. When feeding a dry 
Table 6. Chemical composition of fecal samples and total-tract digestibility

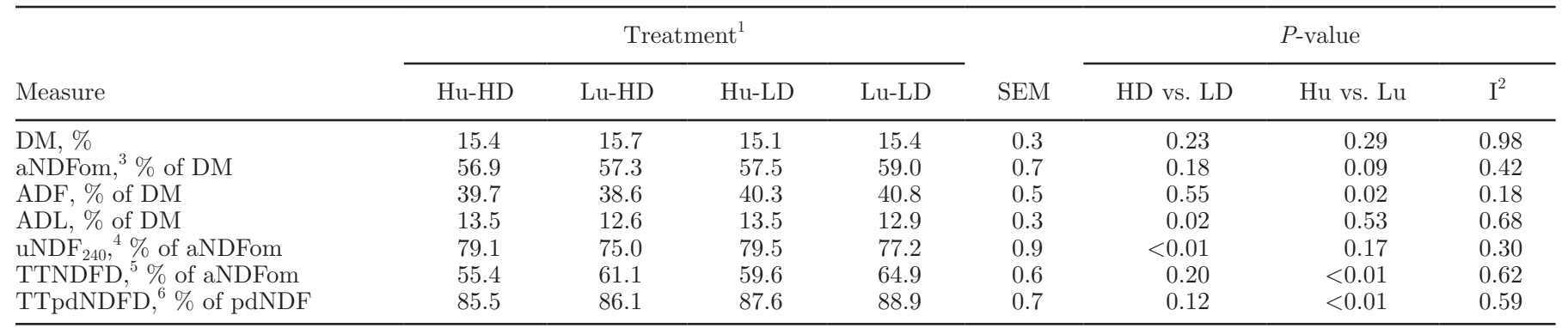

${ }^{1} \mathrm{Hu}-\mathrm{HD}=$ high $\mathrm{uNDF}_{240}$ content, highly digestible alfalfa hay; Lu-HD = low $\mathrm{uNDF}_{240}$ content, highly digestible alfalfa hay; Hu-LD = high $\mathrm{uNDF}_{240}$ content, low-digestible alfalfa hay; Lu-LD = low $\mathrm{uNDF}_{240}$ content, low-digestible alfalfa hay.

${ }^{2} \mathrm{I}=$ effect of the interaction among treatments.

${ }^{3}$ aNDFom $=$ amylase- and sodium sulfite-treated NDF with ash correction.

${ }^{4} \mathrm{uNDF}_{240}=$ undigested NDF estimated via 240 -h in vitro fermentation.

${ }^{5}$ TTNDFD $=$ total-tract digestibility of the aNDFom fraction.

${ }^{6} \mathrm{TTN}$ dDFD $=$ total-tract digestibility of the potentially digestible NDF fraction (pdNDF).

TMR including finely chopped alfalfa and straw, the suggested level of $\mathrm{uNDF}_{240}$ intake, to maintain healthier rumen condition, should be approximately $0.48 \%$ of live BW, whereas the minimum accepted amount should be over $0.40 \%$. The use of rations with very low peNDF levels could be acceptable only when forage aNDFom remains up to 24 to $25 \%$ of dietary DM. The inclusion of soybean hulls to balance the aNDFom does not appear to be an effective way to reduce risk of subclinical acidosis (as assessed by ruminal $\mathrm{pH}$ ), even if the starch content of the diet is low $(<24 \%$ of DM).

\section{ACKNOWLEDGMENTS}

This study was supported by the Emilia Romagna regional law n.28/98, as part of the project "Innovazione alimenti zootecnici" coordinated by Centro Ricerche Produzioni Animali, Reggio Emilia, Italy.

\section{REFERENCES}

Allen, M. S., and P. Piantoni. 2014. Carbohydrate nutrition. Managing energy intake and partitioning through lactation. Vet. Clin. North Am. Food Anim. Pract. 30:577-597.

AOAC. 1990. Official Methods of Analysis. 15th ed. Assoc. Off. Anal. Chem., Arlington, VA.

Bayat, A. R., M. Rinne, K. Kuoppala, S. Ahvenjarvi, A. Vanhatalo, and P. Huhtanen. 2010. Ruminal large and small particle kinetics in dairy cows fed red clover and grass silages harvested at twostages of growth. Anim. Feed Sci. Technol. 155:86-98.

Conrad, H. R., A. D. Pratt, and J. W. Hibbs. 1964. Regulation of feed intake in dairy cows. I. Change in importance of physical and physiological factors with increasing digestibility. J. Dairy Sci. $47: 54-62$.

Ferraretto, L. F., A. C. Fonseca, C. J. Sniffen, A. Formigoni, and R. D. Shaver. 2015. Effect of corn silage hybrids differing in starch and neutral detergent fiber digestibility on lactation performance and total-tract nutrient digestibility by dairy cows. J. Dairy Sci. 98:395-405.
Fustini, M., A. J. Heinrichs, A. Palmonari, and A. Formigoni. 2016 Farm characteristics and TMR particle size issues on Parmigiano Reggiano farms in Northern Italy. Prof. Anim. Sci. 32:869-873.

Fustini, M., A. Palmonari, E. Bucchi, A. J. Heinrichs, and A. Formigoni. 2011. Chewing and ruminating with various forage qualities in non-lactating dairy cows. Prof. Anim. Sci. 27:352-356.

Fustini, M., A. Palmonari, G. Canestrari, and A. Formigoni. 2010. Balancing carbohydrate in dry rations for dairy cows. Pages 301-302 in Proc. International Symposium on Energy and Protein Metabolism and Nutrition, Parma, Italy. Wageningen Academic Publishers, Wageningen, the Netherlands.

Goering, H. K., and P. J. Van Soest. 1970. Forage Fiber Analysis (Apparatus, Reagents, Procedures, and Some Applications). Agriculture Handbook No. 379. ARS-USDA, Washington, DC.

Huhtanen, P., U. Asikainen, M. Arkkila, and S. Jaakkola. 2007. Cell wall digestion and passage kinetics estimated by marker and in situ methods or by rumen evacuations in cattle fed hay 2 or 18 times daily. Anim. Feed Sci. Technol. 133:206-227.

Huhtanen, P., E. Detmann, and S. J. Krizsan. 2016. Prediction of rumen fiber pool in cattle from dietary, fecal, and animal variables. J. Dairy Sci. 99:5345-5357.

Kammes, K. L., and M. S. Allen. 2012. Rates of particle size reduction and passage are faster for legume compared with cool-season grass, resulting in lower rumen fill and less effective fiber. J. Dairy Sci. 95:3288-3297.

Kendall, C., C. Leonardi, P. C. Hoffman, and D. K. Combs. 2009. Intake and milk production of cows fed diets that differed in dietary neutral detergent fiber and neutral detergent fiber digestibility. J. Dairy Sci. 92:313-323.

Klevenhusen, F., P. Pourazad, S. U. Wetzels, M. Qumar, M. A. KholParisini, and Q. Zebeli. 2014. Technical note: Evaluation of a realtime wireless $\mathrm{pH}$ measurement system relative to intraruminal differences of digesta in dairy cattle. J. Anim. Sci. 92:5635-5639.

Kmicikewycz, A. D., and A. J. Heinrichs. 2015. Effect of corn silage particle size and supplemental hay on rumen $\mathrm{pH}$ and feed preference by dairy cows fed high-starch diets. J. Dairy Sci. 98:373-385.

Krizsan, S. J., S. Ahvenjarvi, and P. Huhtanen. 2010. A meta-analysis of passage rate estimated by rumen evacuation with cattle and evaluation of passage rate prediction models. J. Dairy Sci. 93:5890-5901.

Krizsan, S. J., L. Nyholm, J. Nousiainen, K. H. Südekum, and P. Huhtanen. 2012. Comparison of in vitro and in situ methods in evaluation of forage digestibility in ruminants. J. Anim. Sci. 90:3162-3173.

Lammers, B. P., D. R. Buckamster, and A. J. Heinrichs. 1996. A simple method for the analysis of particle sizes of forage and total mixed rations. J. Dairy Sci. 79:922-928. 
Mertens, D. R. 1997. Creating a system for meeting the fiber requirements of dairy cows. J. Dairy Sci. 80:1463-1481.

Mertens, D. R., M. Allen, J. Carmany, J. Clegg, A. Davidowicz, M. Drouches, K. Frank, D. Gambin, M. Garkie, B. Gildemeister, D. Jeffress, C. S. Jeon, D. Jones, D. Kaplan, G. N. Kim, S. Kobata, D. Main, X. Moua, B. Paul, J. Robertson, D. Taysom, N. Thiex, J. Williams, and M. Wolf. 2002. Gravimetric determination of amylase-treated neutral detergent fiber in feeds with refluxing in beakers or crucibles: Collaborative study. J. AOAC Int. 85:1217-1240.

Mertens, D. R., and P. Huhtanen. 2007. Grass forages: Dynamics of digestion in the rumen. Pages 1-20 in Proc. New York Ruminant Health-Nutrition Conf., Syracuse, NY and 47th Annual New England Dairy Feed Conf., West Lebanon, NH. Cornell University, Ithaca, NY.

Mordenti, A. L., N. Brogna, F. Merendi, G. Canestrari, M. Dall'Olio, G. Biagi, and A. Formigoni. 2015. Effect of feeding whole soybean and linseed on milk and Parmigiano Reggiano cheese lipid fraction. Prog. Nutr. 17:220-230.

Oba, M., and M. S. Allen. 1999. Evaluation of the importance of NDF digestibility: Effects on dry matter intake and milk yield of dairy cows. J. Dairy Sci. 82:589-596.

Palmonari, A., M. Fustini, G. Canestrari, E. Grilli, and A. Formigoni. 2014. Influence of maturity on alfalfa hay nutritional fractions and indigestible fiber content. J. Dairy Sci. 97:7729-7734.
Palmonari, A., A. Gallo, M. Fustini, G. Canestrari, F. Masoero, C. J. Sniffen, and A. Formigoni. 2016. Estimation of the indigestible fiber in different forage types. J. Anim. Sci. 94:248-254.

Schirmann, K., N. Chapinal, D. M. Weary, W. Heuwieser, and M. A. G. von Keyserlingk. 2012. Rumination and its relationship to feeding and lying behavior in Holstein dairy cows. J. Dairy Sci. 95:3212-3217.

Schirmann, K., M. A. G. von Keyserlingk, D. M. Weary, D. M. Veira, and W. Heuwieser. 2009. Technical note: Validation of a system for monitoring rumination in dairy cows. J. Dairy Sci. 92:6052-6055.

Tilley, J. M. A., and R. A. Terry. 1963. A two-stage technique for the in vitro digestion of forage crops. J. Br. Grassl. Soc. 18:104-111.

Van Amburgh, M. E., E. A. Collao-Saenz, R. J. Higgs, D. A. Ross, E. B. Recktenwald, E. Raffrenato, L. E. Chase, T. R. Overton, J. K Mills, and A. Foskolos. 2015. The Cornell Net Carbohydrate and Protein System: Updates to the model and evaluation of version 6.5. J. Dairy Sci. 98:6361-6380. https://doi.org/10.3168/jds.20159378.

Van Soest, P. J. 1994. Nutritional Ecology of the Ruminant. Cornell Univ. Press, Ithaca, NY.

Voelker Linton, J. A., and M. S. Allen. 2008. Nutrient demand interacts with forage family to affect intake and digestion responses in dairy cows. J. Dairy Sci. 91:2694-2701. 